\title{
THE HYBRID ORIGIN \\ OF CALAMAGROSTIS $\times$ GRACILESCENS (POACEAE) IN POLAND INFERRED FROM MORPHOLOGY AND AFLP DATA
}

\author{
Beata PaszKo ${ }^{1}$, MARCIN NoBis $^{2}$ \\ ${ }^{1}$ W. Szafer Institute of Botany, \\ Polish Academy of Sciences \\ Lubicz 46, 31-512 Kraków, Poland \\ e-mail: b.paszko@botany.pl \\ 2 Department of Plant Taxonomy and Phytogeography, \\ Jagiellonian University \\ Kopernika 27, 31-501 Kraków, Poland
}

(Received: March 23, 2009. Accepted: January 18, 2010)

\begin{abstract}
The morphology of Calamagrostis canescens and C. stricta recorded in the Małopolska Upland (the vicinity of Zbijów Mały, ca. $10 \mathrm{~km}$ northeast of the town of Skarżysko-Kamienna, Central Poland) was examined due to intermediate individuals found in sympatric populations of these species. Both putative parents as well as individuals that appeared hybrid-like were found in an extensive, wet hay-meadow. Various vegetative and reproductive characteristics were studied to identify hybrids. Interestingly, Polish accessions of $C$. $\times$ gracilescens exhibited some degree of morphological intermediacy but resembled C. stricta in spikelet morphology. Branching of the midculm, the number of nodes per culm, callus hair length and relative callus hair length are the best characters to distinguish the Polish C. × gracilescens. AFLP analysis proved to be suitable for detecting recent hybridization events between $C$. canescens and $C$. stricta. Analysis of the Bayesian clustering analysis showed that $C$. $\times$ gracilescens were subjected to gene flow from the $C$. canescens gene pool as well as from the C. stricta gene pool.
\end{abstract}

KEY WORDS: Calamagrostis $\times$ gracilescens, $C$. canescens, $C$. stricta, hybrid, habitat conditions, morphology, AFLP markers, gene flow.

\section{INTRODUCTION}

With approximately 270 species, Calamagrostis Adans. sensu Clayton and Renvoize (1986) is one of the largest genera in the family Poaceae. As is the case with many grass genera, an important feature of Calamagrostis is the prevalence of interspecific hybrids (Nygren 1962). There are at least 15 hybrids given by Conert (1989) in Central Europe and 20 listed by Tzvelev (1976) in the former USSR within the genus Calamagrostis alone. The evidence for hybrids is usually derived from studies on their morphology and reproductive biology (Nygren 1962; Scholz 1964; Crackles 1994, 1995). Calamagrostis hybrids vary considerably in their frequency and distribution. Some are found at numerous localities across Europe, whereas others are restricted to single locations.

The hybrid between Calamagrostis canescens (Weber) Roth and C. stricta (Timm) Koeler [=C. neglecta (Ehrh.) Gaertn.] was for a long time given the rank of a species and was named $C$. gracilescens Blytt, a name which also included a number of apomictic derivatives (Nygren 1946, page 205). At present it is known as $C$. $\times$ gracilescens (Blytt) Blytt. It is a very rare hybrid in Central Europe and the largest concentrations of its localities have been reported from southern Sweden and Finland (Palmgren 1933-1934; Nygren 1962; Hämet-Ahti et al. 1998; Karlsson and Christofferson 2007). Single localities of this hybrid taxon are known from the Netherlands, Britain and Norway (Holmberg 1922; Corporaal 1984; Crackles 1994, 1995). In Britain, $C . \times$ gracilescens has the status of a rare species (Preston et al. 2002; Cheffings 2004) and is classified as vulnerable by Cheffings et al. (2005).

Populations of Calamagrostis canescens and C. stricta are known in the Małopolska Upland (Central Poland), where they are distributed throughout the region. The two species have usually been delimited from each other based on spikelet traits, especially the length of callus hairs surrounding the florets, length of lemma awn and position of 
awn insertion on the lemma, as well as culm traits such as the number of culm nodes, culm branching and the structure of the upper leaf surface. Typical specimens can be classified appropriately using these characters. C. canescens and $C$. stricta occasionally occur sympatrically. At Zbijów Mały village (Małopolska Upland), plants having certain morphological features intermediate between $C$. canescens and $C$. stricta were present together with the two species and were believed to be their hybrid: Calamagrostis $\times$ gracilescens (Blytt) Blytt (its occurrence in Poland was mentioned by Nobis (2007) and Paszko and Nobis (2007).

The aim of this paper is to evaluate characters used to distinguish a hybrid between $C$. canescens and $C$. stricta. A population of the putative hybrid $C$. $\times$ gracilescens is examined to test the current view that this taxon arose from hybridization between $C$. canescens and $C$. stricta. The structure of phenotypic variation in morphological characters is therefore analyzed to investigate the relationship between the hybrids and their putative parents. It should help to exclude characters that were considered discriminatory by previous authors but display significant low-scale variation. In this study, an AFLP marker system has been used with the objective of clarifying the taxonomic status of $C$. $\times$ gracilescens compared to its putative parental species.

\section{MATERIAL AND METHODS}

\section{Specimens}

Field observations were carried out in the years 2002-2007. Detailed investigations were performed in early July 2004 and repeated in the seasons of 2005, 2006, and 2007. Phytosociological relevés were performed using either the Braun-Blanquet method or floristic checklists compiled at the sites where C. $\times$ gracilescens plants and other accompanying plants formed homogenous patches of vegetation (Nobis 2007). The nomenclature follows relevant authors: vascular plant species - Mirek et al. (2002), mosses Ochyra et al. (2003); the names of syntaxa are given after Matuszkiewicz (2001). The herbarium material is deposited in the herbarium of the Institute of Botany, Polish Academy of Sciences (KRAM) and in the herbarium of the Institute of Botany, Jagiellonian University (KRA) in Kraków.

\section{Analysis of morphological characters}

Morphological characters that were investigated are those that commonly separate the two parental species. They included the following culm characters: culm length, panicle length, leaf length and width (at the second node from the top), presence of long white hairs on upper leaf surfaces ( 0 - not hairy, 1 - sparse hairs, 2 - hairy), number of culm nodes, culm branching (at the second node from the top), length of the basal branch of the panicle, peduncle length, as well as the following spikelet characters: lower and upper glume length and width (LGL, LGW, UGL, UGW), lemma and palea length (LL, PL), callus hair length (CHL), rachilla extension length (RL) (if absent, code: 0), rachilla extension length with hairs (RHL), awn length (AL) and awn insertion (AWNINS) (measured as the length from the base of the lemma to the point of awn insertion). Characters were scored for 124 plants collected in Zbijów Mały. Measurements of the length and width of the leaf blade were done by taking the second leaf from the top of the culm. One well-developed spikelet per individual was used for measurement of spikelet characters. Measurements of spikelet characters were taken with a stereo microscope (Nikon SMZ-10A) with $\times 20$.

Data were analyzed using Statistica ver. 8.0 for Windows (StatSoft 2007). Differences in the means of three groups (two parental species and one hybrid population) for morphological characters were examined using oneway analysis of variance (ANOVA). Principal Component Analysis (PCA on the correlation matrix) was applied to examine morphological variation patterns in $C$. xgracilescens and its putative parents.

\section{Amplified fragment length polymorphism (AFLP)}

Fifty three leaf samples of $C$. × gracilescens, $C$. canescens, and C. stricta from Poland, Czech Republik, Sweden, Finland, and Iceland were collected in silica gel prior to the AFLP analysis. Nineteen accessions of $C$. $\times$ gracilescens were taken into AFLP analysis. Eight Polish accessions came from the locality of Zbijów Mały (Central Poland). Eleven Swedish accessions were descended from 3 localities: seven from Kiaholmen Island, three from Hunna village (both in the vicinity of Lake Skatelövfjorden in Småland Prov.), and one from the Singö Island (Upland Prov.). Eighteen accessions of $C$. canescens from Poland, Czech Republik, Sweden, and Finland, and 16 of $C$. stricta from Poland, Sweden, and Iceland were taken into account for comparison (see Appendix 1). Total genomic DNA was extracted from $20 \mathrm{mg}$ of dried leaf tissue following DNeasy Plant Mini Kit protocol supplied by the manufacturer (Qiagen). AFLP analysis was carried out according to Vos et al. (1995) with minor modification. Preamplification and selective amplification were performed as described by Vos et al. (1995). Three primer pairs (E+AGT/M+CAG, $\mathrm{E}+\mathrm{ATG} / \mathrm{M}+\mathrm{CGC}$, and $\mathrm{E}+\mathrm{ATT} / \mathrm{M}+\mathrm{CTA}$ ) were chosen for selective PCR based on a preliminary survey of 12 primer pairs. The resulting PCR products were separated with the internal size standard GeneScan 500Rox (Applied Biosystems) in an automated DNA sequencer ABI 3100-Avant (Applied Biosystems) and analysed using GeneMapper software packages, version 4.0 (Applied Biosystems). AFLP bands ranging from 50 to 500 base pairs were scored.

Unweighted pair group method with arithmetic mean (UPGMA) was applied with restriction sites similarity coefficiency method as described by Nei and Li (1979) using Treecon for Windows, version $1.3 \mathrm{~b}$ (Van de Peer \& De Wachter 1994). Internal support for groupings was assessed using the bootstrap procedure of Felsenstein (1985) with 2000 replications. Pairwise fixation index $\left(\mathrm{F}_{\mathrm{ST}}\right)$ between pairs of taxa was assed using Arlequin ver. 3.0 (Excoffier et al. 2005). Principal components analysis (PCA on the variance-covariance matrix) was used as to explore the main patterns of genetic variation of $C$. $\times$ gracilescens in comparison with its putative parental species. These analyses were conducted using Statistica ver. 8.0 for Windows (StatSoft 2007). Usually, the PCA of the covariance matrix is meaningful only if the variables are expressed in the same units. Results of PCA were consistent with Principal Coordinates Analysis performed using Euklidean distances. The gene flow between the two putative parental species of $C . \times$ gracilescens was investigated using the Bayesian clustering approach implemented in STRUCTURE (version 2.3; Pritchard et al. 2009). 


\section{RESULTS}

\section{Locality}

The collection site is situated ca. $0.5 \mathrm{~km} \mathrm{NW}$ of the Zbijów Mały village (ATPOL grid squares: EE47 00, based on cartogram units $2.5 \times 2.5 \mathrm{~km}$, Zając 1978) and SE of the Zbijów Mały - Stary Mirów road (Fig. 1), in hay-meadows along a water-course (right-hand side affluent of the Iłżanka river). Its geographic coordinates are $51^{\circ} 10^{\prime} 29.2^{\prime}$, $\mathrm{N} / 21^{\circ} 02^{\prime} 15.5^{\prime \prime} \mathrm{E}$ and it is located at an altitude of ca. 190 m. Zbijów Mały is situated ca. $10 \mathrm{~km} \mathrm{NW}$ of the town of Skarżysko-Kamienna (NE part of the Małopolska Upland, Central Poland).

\section{Share in plant communities}

Calamagrostis canescens is a species characteristic of forest communities belonging to the class Alnetea glutinosae (Matuszkiewicz 2001); it grows, however, in extensive wet hay-meadows, in a fen and by a water-course (to the left of the road connecting Mirów and Zbijów Mały) in Zbijów Mały. At this locality, $C$. canescens forms its own, local community, characterized by a marked domination of $C$. canescens (forming beds) and a small coverage of other plant species. $C$. canescens was also observed on the edge of a drainage ditch and on the margins of a mixed forest.

C. stricta is a species characteristic of peatlands belonging to the class Scheuzerio-Caricetea nigrae. It grows mainly in drainage ditches or near them at the present locality. Its coverage is extensive in some parts of the fen (Nobis and Piwowarczyk 2004). C. stricta has the highest share in the communities examined and its coverage ranges between + and 5 (Table 1 ).

C. $\times$ gracilescens grows mainly in wet hay-meadows (phytosociological relevé no. 6) belonging to the class $M o$ linio-Arrhenetheretea, especially the order Molinietalia. It was also observed in their surroundings: in a fen representing the class Scheuzerio-Caricetea nigrae and in drainage ditches (nearly forming beds in places). Therefore, a great participation of rush species, especially of the Magnocaricion alliance, and fen species is noted in the plant communities documented phytosociogically. The taxon grows almost exclusively close to its parents, either both or one of them.

\section{Morphological analysis}

C. stricta, C. canescens and several other interesting specimens were collected during field studies in the vicinity of Zbijów Mały. While they appeared to be similar to $C$. stric$t a$ at first glance, the specimens turned out to resemble $C$. canescens upon closer examination; the two species, however, are completely different in their external appearance. Culms of $C$. canescens plants from Zbijów Mały are usually branched in the middle part of the stem and 5-7 noded. The short awn, up to $0.65 \mathrm{~mm}$ long, is apical, rarely inserted below the lemma apex. The lower glume is 4.5-6.4 times longer than wide. The lemma is ringed at the base with white callus hairs, 3.0-4.8 $\mathrm{mm}$ long, longer than lemma length. Leaves are limp, scarcely ribbed and usually with white long hairs on the upper leaf surface, these being about $1 \mathrm{~mm}$ long (Table 2). Culms of C. stricta collected in Zbijów Mały are always unbranched in the middle part of the stem and 2-5 noded. The lemma bears a fine straight awn on the back, 1.5-2.5 mm long. The point of awn insertion is between lower one-fifth and two-fifth above the base. The lower glume is 2.6-4.1 times longer than wide. The lemma is ringed at the base with white callus hairs, 1.6$2.75 \mathrm{~mm}$ long, up to 0.9 long as the lemma. The upper leaf surface of $C$. neglecta is prominently vein-ridged and scabrous. Range values calculated for the best characters to differentiate the species are presented in Table 2.

The intermediate nature of the Calamagrostis canescens $\times C$. stricta hybrids recorded in Zbijów Mały prompted a more extensive survey of morphological characters of the populations. Calamagrostis canescens, C. stricta and $C$. $\times$ gracilescens from Zbijów Mały did not differ significantly $(P>0.05)$ according to seven characters: panicle length,

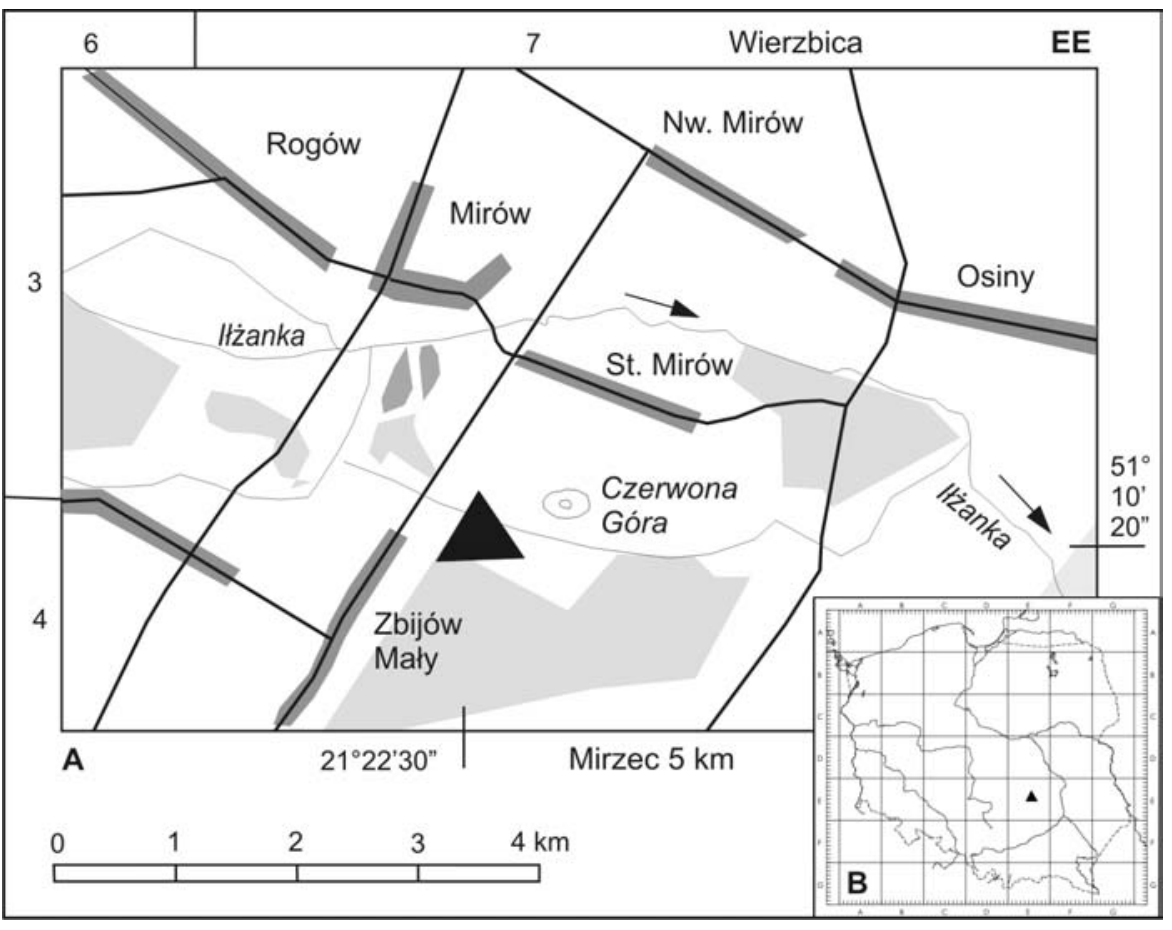

Fig. 1. The locality of Calamagrostis $\times$ gracilescens located nearby Zbijów Mały village (Central Poland) - 
TABLE 1. Plant communities with Calamagrostis $\times$ gracilescens (Blytt) Blytt and its parental species.

\begin{tabular}{|c|c|c|c|c|c|c|c|}
\hline Number of relevé & 1 & 2 & 3 & 4 & 5 & 6 & $\mathrm{C}$ \\
\hline Date & 06.07 .04 & 06.07 .04 & 06.07 .04 & 29.06 .06 & 29.06 .06 & 05.07 .05 & $\mathrm{n}$ \\
\hline Cover of herb layer c (\%) & 100 & 100 & 95 & 95 & 90 & 100 & S \\
\hline Cover of mosses layer d (\%) & exiguously & exiguously & exiguously & 5 & exiguously & 30 & t \\
\hline Area of relevé $\left(\mathrm{m}^{2}\right)$ & 150 & 100 & 100 & 50 & 100 & 70 & a \\
\hline Altitude a.s.l. & 190 & 190 & 190 & 190 & 190 & 190 & $\mathrm{c}$ \\
\hline Number of species & 25 & 26 & 28 & 30 & 24 & 26 & $\mathrm{y}$ \\
\hline Calamagrostis $\times$ gracilescens & . & . & + & . & + & 5 & III \\
\hline \multicolumn{8}{|l|}{ Cl. Scheuzerio-Caricetea nigrae } \\
\hline Calamagrostis neglecta & 5 & 5 & 4 & 4 & 5 & . & $\mathrm{V}$ \\
\hline Comarum palustre & 2 & 1 & + & 1 & 1 & + & $\mathrm{V}$ \\
\hline Carex nigra & . & . & . & . & + & + & II \\
\hline Stellaria palustris & + & . & + & . & . & . & II \\
\hline Ranunculus flammula & . & . & . & 2 & . & + & II \\
\hline Poa pratensis & + & + & + & 2 & + & . & $\mathrm{V}$ \\
\hline Ranunculus acer & + & + & + & + & + & . & $\mathrm{V}$ \\
\hline Rumex acetosa & + & + & + & + & + & . & $\mathrm{V}$ \\
\hline Cardamine pratensis & . & + & + & 1 & + & + & $\mathrm{V}$ \\
\hline Festuca rubra & + & + & + & . & . & + & IV \\
\hline Poa trivialis & . & . & + & + & . & 1 & III \\
\hline Plantago lanceolata & . & + & . & . & . & + & II \\
\hline \multicolumn{8}{|c|}{ O. Molinietalia and characteristic of $*$ its associations } \\
\hline *Caltha palustris & + & + & 1 & 1 & + & 1 & $\mathrm{~V}$ \\
\hline Equisetum palustre & 1 & + & + & 1 & + & 1 & $\mathrm{~V}$ \\
\hline Deschampsia caespitosa & 1 & 1 & + & 3 & 2 & 2 & $\mathrm{~V}$ \\
\hline *Juncus effusus & 1 & + & + & 1 & + & + & $\mathrm{V}$ \\
\hline Galium uliginosum & 1 & + & + & 1 & + & . & $\mathrm{V}$ \\
\hline Lotus uliginosus & + & + & + & . & + & + & $\mathrm{V}$ \\
\hline *Lythrum salicaria & $\mathrm{r}$ & . & 1 & 1 & + & . & IV \\
\hline Cirsium palustre & + & + & + & . & + & . & IV \\
\hline \multicolumn{8}{|l|}{ Cl. Phragmitetea } \\
\hline Galium palustre & + & + & + & 2 & 1 & 1 & $\mathrm{~V}$ \\
\hline Poa palustris & + & . & + & 2 & 1 & + & $\mathrm{V}$ \\
\hline Carex rostrata & . & . & + & 1 & 2 & 1 & IV \\
\hline Carex gracilis & . & + & + & . & . & . & II \\
\hline Carex paradoxa & . & + & . & . & . & . & $\mathrm{I}$ \\
\hline \multicolumn{8}{|l|}{$\mathrm{Cl}$. Alnetea glutinosae } \\
\hline Calamagrostis canescens & + & . & 3 & 1 & . & + & IV \\
\hline
\end{tabular}

Sporadic: Cl. Scheuzerio-Caricetea nigrae: Agrostis canina 3, Menyanthes trifoliata 6, Veronica scutellata 4; Cl. Molinio-Arrhenatheretea: Festuca pratensis 4; O. Molinietalia: Lychnis flos-cuculi 5, Lysymachia vulgaris 5(1), Myosotis palustris 4, Scirpus sylvaticus 2; Other: Agrostis capillaris 5(1), 6; Anthoxanthum odoratum 2, 6(1); Brachythecium sp. 1(1); 2(1); 3, 5(1), 6; Caliergonella cuspidata 1(1), 2(1), 3(+), 4(1), 5, 6(2); Epilobium palustre 4, 6; Euchrynchium sp. 1, 2, 3, 4, 6; Holcus lanatus 6(1); Mentha sp. 4; Plagiomnium sp. 1, 2, 3, 4; Plantago intermedia 4; Ranunculus repens 4(1); Salix cinerea (c) 1.

leaf length, ligule length, peduncle length, lemma length, palea length and hairiness of the upper leaf surface (Table $2)$. These characters were excluded from PCA analysis (Fig. 2). Other characters selected for examination were shown to differ significantly $(P<0.001)$ among the three groups of taxa and a few of them could distinguish the hybrid taxon.

C. $\times$ gracilescens is very similar to $C$. stricta and significantly differs from it only with regard to four characters: (1) number of culm nodes, (2) callus hair length, (3) callus hair length/lemma length ratio, and (4) mid-culm branching. Low F-values in ANOVA indicate a greater similarity between $C$. $\times$ gracilescens and $C$. canescens in relation to the first three characters. $C$. $\times$ gracilescens considerably differs from $C$. canescens by all of the characters studied. However, the differences are very small in the case of many characters, the F-value is lower than 50 and therefore the differences are not of any taxonomical significance. Some intermediate characters were detected: callus hair length and the callus hair length/lemma length ratio. The number of culm nodes in $C$. Xgracilescens overlaps with both parental species (Table 2). The hybrid expressed the upper leaf surface characteristic of $C$. stricta. Adaxial surfaces of the leaves in the hybrid and $C$. stricta are prominently ribbed, with wide grooves, scabrous and hairless or sparsely hairy compared to leaf surfaces weakly ribbed and hairy or nonhairy in $C$. canescens.

As the PCA of these morphological measurements shows, $79 \%$ of the variation could be explained by two principal components. A graph of these showed that $C$. $c a$ nescens and $C$. stricta formed two distinct clouds (Fig. 2). Individuals of Polish accessions of $C$. $\times$ gracilescens are closer to the cloud of data points of $C$. stricta, partly overlapping with it. Swedish accessions of $C . \times$ gracilescens are located more in the center, close to an average of the scores of the parent species. The first principal component expres- 
TABLE 2. Morphological variation among the hybrid and its parents, $C$. canescens and $C$. stricta for 21 characters from plants collected at Zbijów Mały near Skarżysko-Kamienna (Central Poland). $\mathrm{N}$ - number of individuals studied. Characters indicated by asterisk (*) were included in a PCA analysis.

\begin{tabular}{|c|c|c|c|}
\hline Character & $\begin{array}{c}\text { C. canescens } \\
\mathrm{N}=31 \\
\text { Mean } \\
\text { Min-max }\end{array}$ & $\begin{array}{c}C . \times \text { gracilescens } \\
\mathrm{N}=30 \\
\text { Mean } \\
\text { Min-max }\end{array}$ & $\begin{array}{c}\text { C. stricta } \\
\mathrm{N}=63 \\
\text { Mean } \\
\text { Min-max }\end{array}$ \\
\hline culm length $[\mathrm{cm}]$ & $\begin{array}{c}116.9 \\
96.5-137.0\end{array}$ & $\begin{array}{c}99.7 \\
82.0-139.0\end{array}$ & $\begin{array}{c}101.9 \\
71.5-135.0\end{array}$ \\
\hline number of culm nodes* & $\begin{array}{c}6.52 \\
5-7\end{array}$ & $\begin{array}{c}5.17 \\
3-7\end{array}$ & $\begin{array}{c}3.46 \\
3-5\end{array}$ \\
\hline panicle length $[\mathrm{cm}]$ & $\begin{array}{c}16.3 \\
13.0-20.0\end{array}$ & $\begin{array}{c}16.0 \\
10.3-28.5\end{array}$ & $\begin{array}{c}15.2 \\
10.0-25.0\end{array}$ \\
\hline length of bottom branch of the panicle $[\mathrm{cm}]$ & $\begin{array}{c}6.4 \\
4.2-8.0\end{array}$ & $\begin{array}{c}5.3 \\
2.2-9.2\end{array}$ & $\begin{array}{c}4.4 \\
2.2-9.2\end{array}$ \\
\hline peduncle length $[\mathrm{cm}]$ & $\begin{array}{c}41.5 \\
30.3-53.0\end{array}$ & $\begin{array}{c}42.9 \\
27.3-65.0\end{array}$ & $\begin{array}{c}49.1 \\
23-75.7\end{array}$ \\
\hline leaf length $[\mathrm{cm}]$ & $\begin{array}{c}21.8 \\
16.7-31.0\end{array}$ & $\begin{array}{c}21.3 \\
16.2-29.8\end{array}$ & $\begin{array}{c}19.1 \\
13.5-29.0\end{array}$ \\
\hline leaf width $[\mathrm{cm}]^{*}$ & $\begin{array}{c}5.3 \\
4.3-7.5\end{array}$ & $\begin{array}{c}4.1 \\
3.1-5.5\end{array}$ & $\begin{array}{c}3.7 \\
2.8-5.3\end{array}$ \\
\hline upper leaf surface & canescens-like & stricta-like & stricta-like \\
\hline ligule length $[\mathrm{mm}]$ & $\begin{array}{c}2.7 \\
1.0-5.0\end{array}$ & $\begin{array}{c}3.0 \\
1.6-5.5\end{array}$ & $\begin{array}{c}2.2 \\
0.7-6.2\end{array}$ \\
\hline branching of culm* & $87 \%$ & $53 \%$ & $0 \%$ \\
\hline presence of long white hairs on the upper leaf surfaces & $\begin{array}{c}\text { hairless }-3 \\
\text { single hairs }-6 \\
\text { hairy }-22\end{array}$ & $\begin{array}{c}\text { hairless }-0 \\
\text { single hairs }-2 \\
\text { hairy }-28\end{array}$ & $\begin{array}{c}\text { hairless }-23 \\
\text { single hairs }-2 \\
\text { hairy }-38\end{array}$ \\
\hline lower glume length $[\mathrm{mm}]^{*}$ & $\begin{array}{c}4.7 \\
3.85-5.50\end{array}$ & $\begin{array}{c}3.7 \\
3.1-4.4\end{array}$ & $\begin{array}{c}3.6 \\
2.9-4.6\end{array}$ \\
\hline lower glume width $[\mathrm{mm}]^{*}$ & $\begin{array}{c}0.89 \\
0.75-1.05\end{array}$ & $\begin{array}{c}1.08 \\
0.80-1.25\end{array}$ & $\begin{array}{c}1.10 \\
0.90-1.35\end{array}$ \\
\hline lemma length $[\mathrm{mm}]$ & $\begin{array}{c}2.81 \\
2.25-3.2\end{array}$ & $\begin{array}{c}2.89 \\
2.3-3.4\end{array}$ & $\begin{array}{c}2.79 \\
2.35-3.35\end{array}$ \\
\hline awn insertion* & $\begin{array}{c}2.49 \\
1.60-3.00\end{array}$ & $\begin{array}{c}0.78 \\
0.5-1.2\end{array}$ & $\begin{array}{c}0.80 \\
0.5-1.15\end{array}$ \\
\hline lower glume length/lower glume width* & $\begin{array}{c}5.28 \\
4.53-6.4\end{array}$ & $\begin{array}{c}3.47 \\
2.96-4.56\end{array}$ & $\begin{array}{c}3.34 \\
2.56-4.10\end{array}$ \\
\hline callus-hairs length $[\mathrm{mm}]^{*}$ & $\begin{array}{c}3.78 \\
3.0-4.75\end{array}$ & $\begin{array}{c}2.84 \\
2.0-3.55\end{array}$ & $\begin{array}{c}2.05 \\
1.65-2.75\end{array}$ \\
\hline callus hairs length/lemma length* & $\begin{array}{c}1.35 \\
1.03-1.64\end{array}$ & $\begin{array}{c}0.98 \\
0.76-1.16\end{array}$ & $\begin{array}{c}0.73 \\
0.58-0.88\end{array}$ \\
\hline rachilla length $[\mathrm{mm}]^{*}$ & absent or up to 0.35 & $\begin{array}{c}0.53 \\
0.25-0.85\end{array}$ & $\begin{array}{c}0.74 \\
0.50-1.4\end{array}$ \\
\hline relative lemma awn insertion* & $\begin{array}{c}0.89 \\
0.6-1\end{array}$ & $\begin{array}{c}0.27 \\
0.19-0.49\end{array}$ & $\begin{array}{c}0.29 \\
0.18-0.39\end{array}$ \\
\hline awn length $[\mathrm{mm}]^{*}$ & $\begin{array}{c}0.44 \\
0.25-0.65\end{array}$ & $\begin{array}{c}1.76 \\
1.05-2.25\end{array}$ & $\begin{array}{c}1.97 \\
1.45-2.5\end{array}$ \\
\hline
\end{tabular}

sed $69 \%$ of the total variance and is explained by all the characters which were used in the PCA. Strongly negative
$(<-0.70)$ and strongly positive loadings $(>+0.60)$ indicate that all these characters take part in the differentiation of 


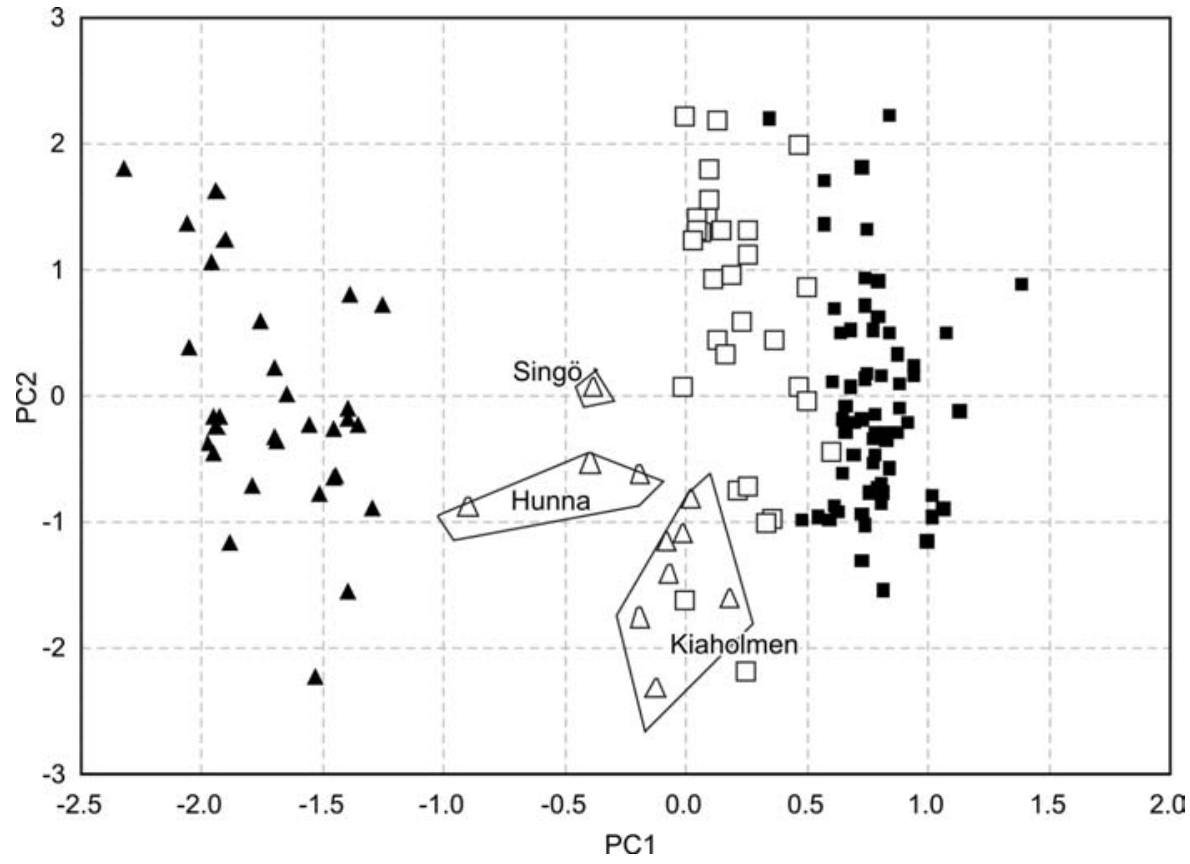

Fig. 2. Two-dimensional ordination diagram of PCA analysis (on the correlation matrix) based on 17 morphological characters. Taxa are indicated as follows: $C$. canescens $(\boldsymbol{\Delta}$ solid triangles), C. stricta ( $\mathbf{\square}$ solid squares), Polish accessions of $C$. $\times$ gracilescens $(\square$ open squares), Swedish accessions of $C . \times$ gracilescens ( $\triangle$ open triangles). the two parental species of $C$. $\times$ gracilescens. The second principal component explaining $11 \%$ of the total variance does not have loadings higher than \pm 0.70 , but has two cross-loadings (with culm branching and lower glume width).

\section{AFLP analysis}

In the 53 studied accessions of Calamagrostis $\times$ gracilescens and its parental species, three primer combinations amplified a total of 563 fragments, 551 of which were polymorphic (Table 3). Of those, 457 were shared by two or more accessions, and thus were potentially informative, whereas 94 were either unique to a single accession or present in all except one. The selective primer pair combinations varied in their ability to detect AFLP variation across Calamagrostis accessions with numbers of detected polymorphic fragments ranging from 120 (E+ATT/M+CTA) to 248 (E+ATG/M+CGC). However, the percentage of potentially informative fragments (out of the total number) generated by each selective primer combination was stable be- tween $80.0 \%(\mathrm{E}+\mathrm{ATT} / \mathrm{M}+\mathrm{CTA})$ and $81.9 \%(\mathrm{E}+\mathrm{ATG} /$ $\mathrm{M}+\mathrm{CGC})$. A significant number of shared AFLP fragments was found in this study: 24 between $C$. $\times$ gracilescens and C. canescens, 16 between $C$. × gracilescens and $C$. stricta, and 14 between $C$. canescens and $C$. stricta (Table 3 ). Species-specific AFLP markers (i.e., bands that are present in all individuals of one species and none of the other) were found. Three $C$. canescens-specific and four $C$. stricta-specific markers were detected. For these seven bands the putative hybrids had usually high band frequencies. None of completely hybrid-specific AFLP markers were noticed.

Relying on the 551 polymorphic AFLP markers, a dendrogram was constructed based on Nei Li's genetic distance using UPGMA methods (Fig. 3). Studied specimens formed three major clusters, which corresponded with three studied taxa of Calamagrostis. C. canescens accessions showed the highest number of shared fragments with $C$. $\times$ gracilescens accessions (Table 3 ), and formed a cluster with them (Fig. 3). Bootstrap support values for branches, which included $C$. $\times$ gracilescens and $C$. stricta were mode-

TABLE 3. Characteristics of fragment variation generated by three primer combinations in the AFLP analysis of 53 accessions of Calamagrostis $\times$ gracilescens and its putative parents. Fragments were scored for each accession within a readable range of 50-500 bp.

\begin{tabular}{|c|c|c|c|c|c|}
\hline \multirow{2}{*}{ Characteristics / primer combinations } & \multicolumn{5}{|c|}{ Calamagrostis $\times$ gracilescens and its parental species } \\
\hline & $\mathrm{E}+\mathrm{AGT} / \mathrm{M}+\mathrm{CAG}$ & $\mathrm{E}+\mathrm{ATG} / \mathrm{M}+\mathrm{CGC}$ & $\mathrm{E}+\mathrm{ATT} / \mathrm{M}+\mathrm{CTA}$ & Total & Mean \\
\hline Total fragments & 195 & 248 & 120 & 563 & 187.7 \\
\hline No. present in all accessions & 7 & 3 & 2 & 12 & 4 \\
\hline No. present in two or more accessions & 158 & 203 & 96 & 457 & 152.3 \\
\hline Potentially informative fragments $(\%)$ & 81.0 & 81.9 & 80.0 & 81.2 & 81.0 \\
\hline No. shared between $C$. canescens and $C$. stricta & 8 & 4 & 2 & 14 & 4.7 \\
\hline No. shared between $C . \times$ gracilescens and $C$. stricta & 10 & 3 & 3 & 16 & 5.3 \\
\hline No. shared between $C$. canescens and $C . \times$ gracilescens & 11 & 9 & 4 & 24 & 8 \\
\hline
\end{tabular}




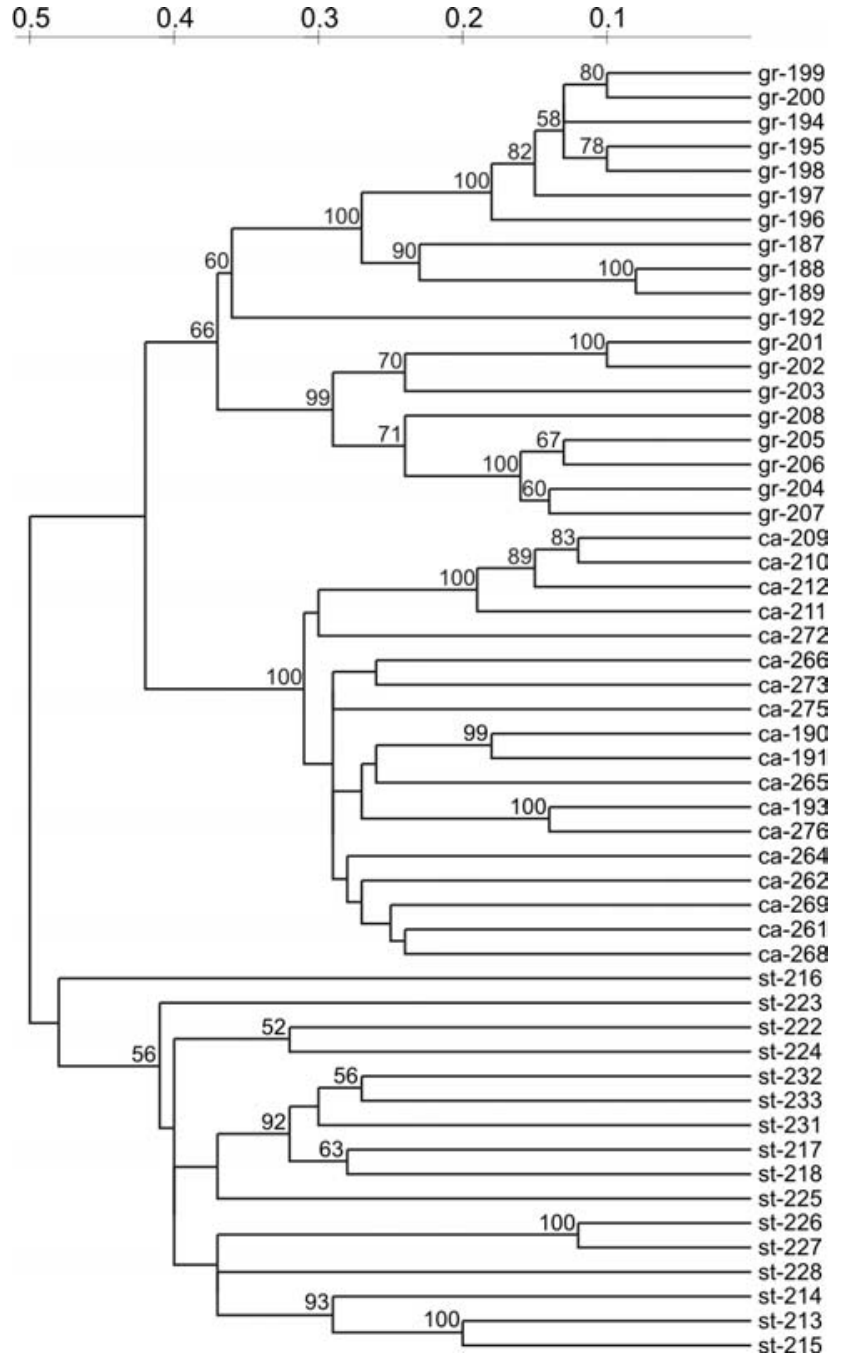

Fig. 3. UPGMA dendrogram of $C$. $\times$ gracilescens and its putative parental species $C$. canescens and $C$. stricta based on based on Nei-Li's genetic distance for 551 AFLP fragments. Bootstrap support values above $50 \%$ are shown. Calamagrostis samples codes see Appendix 1.

rately low, 66\% and 56\%, respectively. Branch, which comprehended accessions of $C$. canescens were very well supported (100\%) (Fig. 3). Two subclusters were possible to be distinguished within $C$. $\times$ gracilescens cluster. The first one included eleven Swedish accessions of $C . \times$ gracilescens from Kiaholmen Island (gr-194-gr-200), Hunna village (gr-187-gr-189), and Singö Island (gr-192). The first two Swedish localities are situated close to each other at Lake Skatelövfjorden (Småland Prov., Alvesta kommun). The latter subcluster comprised eight Polish accessions from the locality Zbijów Mały village (gr-201-gr-208).

High levels of pairwise fixation index $\left(\mathrm{F}_{\mathrm{ST}}\right)$ (0.196-0.386) were observed among the three genetic clusters therefore supporting their existence. The highest value of $\mathrm{F}_{\mathrm{ST}}(0.386)$ was detected for $C$. canescens and $C$. stricta, relatively lower value was assessed for $C$. $\times$ gracilescens and $C$. canescens (0.290), and for $C$. $\times$ gracilescens and C. stricta (0.196).

There were 551 polymorphic markers used in PCA analysis. The first PCA axis accounted for $19.6 \%$ of the variation while the second for $9.1 \%$. A plot of the first two axes resulted in spatial separation of two species along the first and the second axis. The hybrids are distributed within the area between the two species, however Polish accessions are more concentrated towards individuals of $C$. stricta (Fig. 4).

We ran STRUCTURE for 100,000 MCMC steps after a burn-in of 10,000 iterations. The admixture model and performed clustering without population information data, and assumed independent allele frequencies were used (Pritchard et al. 2009). The objective of this analysis was to test whether samples of $C$. $\times$ gracilescens can be classified within or between the putative parental species. Initial simulations in Structure were performed assuming genetic cluster numbers from $K=2-5$. While $\mathrm{K}=2$ resulted in two discrete genetic clusters with the parental samples being placed firmly in either cluster, an increase in $K$ to three, four or five displayed relatively higher $\ln$ likelihood and also higher variance of $\ln$ likelihood.

We concluded that the existence of two genetic clusters best explained the data. Out of 53 samples, 18 samples of C. canescens had high membership value (mean $Q=$ $0.997)$ to $C$. canescens gene pool, 16 samples of $C$. stricta

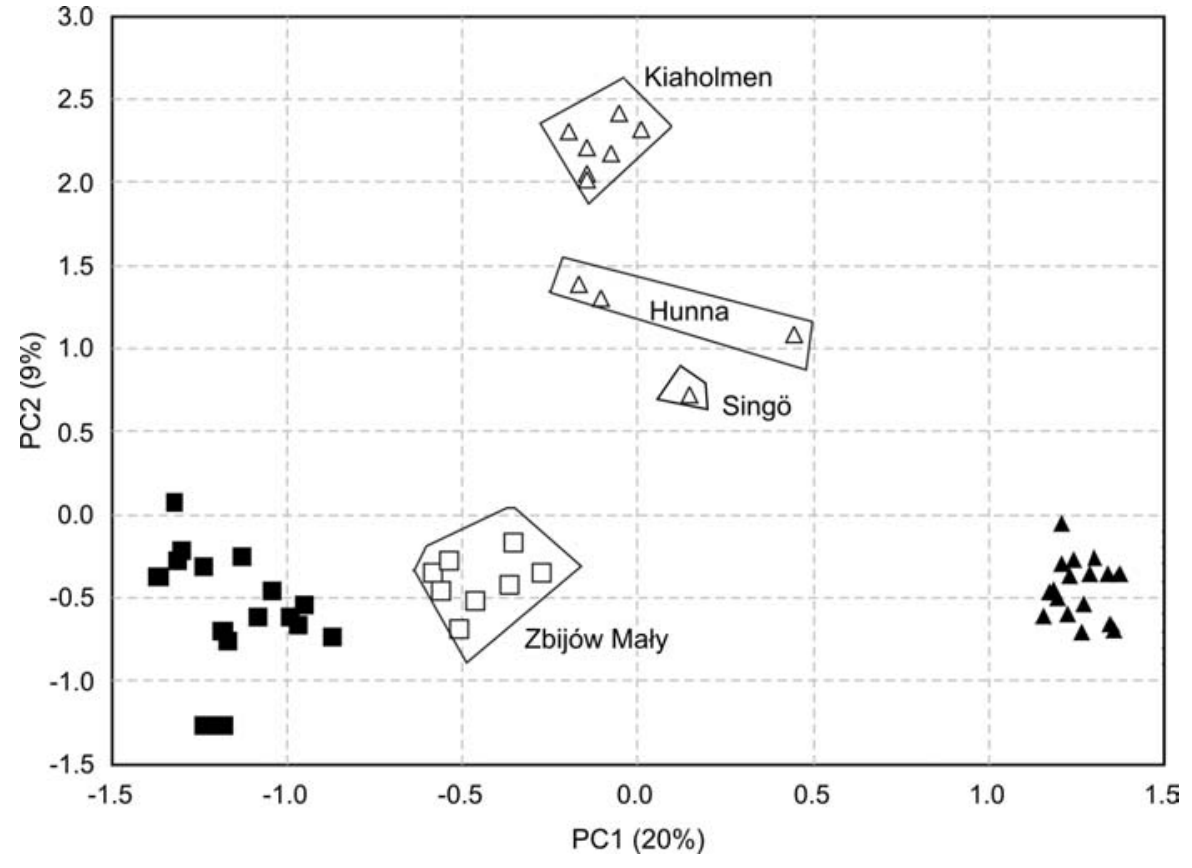

Fig. 4. PCA analysis (on the variance-covariance matrix) of AFLP fragments for $C$. $\times$ gracilescens and its putative parents: $C$. $c a$ nescens ( $\boldsymbol{\Delta}$ solid triangles), C. stricta ( $\boldsymbol{\square}$ solid squares), Polish accessions of $C$. $\times$ gracilescens ( $\square$ open squares), Swedish accessions of $C$. $\times$ gracilescens ( $\triangle$ open triangles). Different Swedish accessions of C. $\times$ gracilescens are shown using polygons. Percentage of the total variance explained by two principal components is given. 


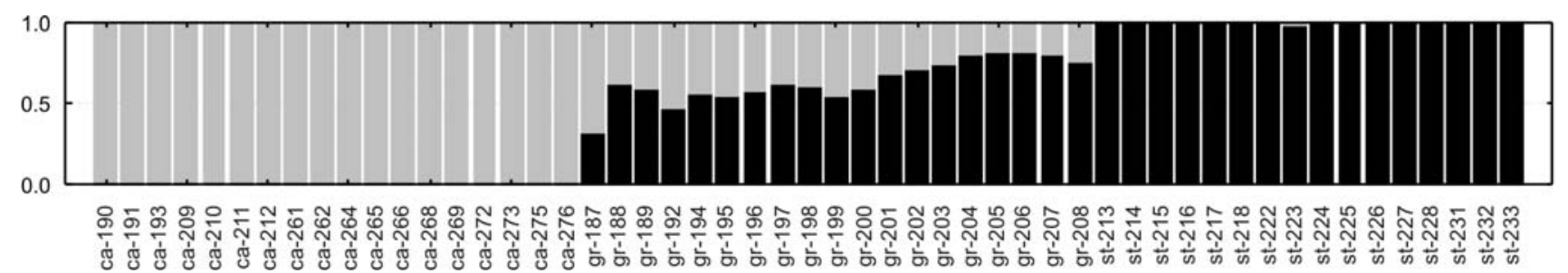

Fig. 5. Coefficients of estimated ancestry per individual $(Q)$ and grouped by taxa. Each individual is represented by a single vertical line broken into two coloured segments, with lengths proportional the individual's ancestry fraction from each of the two biological gene pool: $C$. canescens (gray) and $C$. stricta (black).

fit into $C$. stricta gene pool (mean $Q=0.994)$. Samples of $C$. $\times$ gracilescens had higher membership value to $C$. stricta gene pool, (mean $Q=0.63, \mathrm{SD}=0.13$ ) and lower to $C$. $c a$ nescens gene pool (mean $Q=0.37, \mathrm{SD}=0.13$ ) (Fig. 5, Table 4).

TABLE 4. Proportion of estimated ancestry $(Q)$ of 53 samples of $C$. $\times$ gracilescens and its putative parents. In brackets the number of studied samples of each taxa.

\begin{tabular}{llc}
\hline Taxa & $\begin{array}{c}Q \text { C. canescens pool } \\
\text { Min-max (average) }\end{array}$ & $\begin{array}{c}Q \text { C. stricta pool } \\
\text { Min-max (average) }\end{array}$ \\
\hline C. canescens (18) & $0.996-0.998(0.997)$ & $0.002-0.004(0.003)$ \\
\hline C. $\times$ gracilescens (19) & $0.194-0.689(0.374)$ & $0.311-0.806(0.626)$ \\
\hline C. stricta $(16)$ & $0.001-0.037(0.006)$ & $0.963-0.999(0.994)$ \\
\hline
\end{tabular}

Description of the Zbijów Maty

Calamagrostis $\times$ gracilescens population with reference

to some diagnostic features of its parental species

The description of $C$. $\times$ gracilescens is based on 30 plants examined in the analysis.

Perennial, rhizomatous, forming beds. Culms reaching a height of $82-139 \mathrm{~cm}, 3-7-n o d e d$, peduncle $27-65 \mathrm{~cm}$ long (a feature of $C$. canescens that frequently occurs in the hybrids is culm branching at basal and middle nodes, 16 out of the 30 specimens examined). Leaves green, blade 16-30 $\mathrm{cm}$ long, 3-5.5 mm wide, surface scabrous (rough to the touch), with long white hairs on upper leaf surface as in $C$. canescens, ligule 1.6-5.5 mm long. Panicle C. canescenslike in length, 10-28 cm long. Basal branch of panicle longer than in C. stricta $2.2-9.2 \mathrm{~cm}$, average $5.3 \mathrm{~cm}$ long. Glumes similar to those of $C$. stricta in length to slightly longer, lower glume 3.1-4.4 mm long, 1-veined, upper glume 2.9-4.3 mm long, 3-veined, two lateral nerves very short, and similar to those of $C$. stricta in width, $0.8-1.25 \mathrm{~mm}$ wide. Lemma 2.3-3.4 mm, average $2.9 \mathrm{~mm}$. Callus hairs intermediate in length, 2.0-3.6 mm long, usually more or less equal the floret in length, 0.8-1.2 length of lemma. Awn length and insertion as in C. stricta. Awn dorsal, straight, 1.0-2.3 mm long, arising 0.2-0.5 way up back of lemma. Palea 1.4-2.4 mm long. Spikelet axis (rachilla) prolonged as a minute bristle as in C. stricta, 0.3-0.9 mm long, pilose.

\section{DISCUSSION}

The phenetic analysis of morphological characters examined in this study allows genetic affinities among the taxa to be estimated quantitatively with greater accuracy. Cala- magrostis canescens is morphologically clearly distinct from $C$. stricta at the locality in Zbijów Mały. The most striking observation is that $C$. $\times$ gracilescens is not phenotypically intermediate. However, recent studies by Rieseberg (1995) have shown that morphological characters of hybrids are not always intermediate between those of the parental species and hybrids are actually a mosaic of parental, intermediate and extreme characters. Thus, some traits are more likely to reveal hybrid ancestry than others (Rieseberg 1995). Extreme characters were not detected in $C$. $\times$ gracilescens. It was evident that $C . \times$ gracilescens is closer to $C$. stricta for the majority of the morphological characters examined in the analysis. A smaller set of characters (mid-culm branching, callus hair length, relative callus hair length and number of culm nodes) indicated a closer affinity between the hybrid and $C$. canescens.

The occurrence of hybrid populations at 3-4 sites as beds 4-5 $\mathrm{m}$ in diameter and some smaller tufts suggests that they are a result of single hybridization events and persist through vegetative reproduction. The ability of $C$. Xgracilescens to reproduce in nature considerably increases the number of biotypes in the complex. Like $C$. canecens and C. stricta, C. Xgracilescens has the power to form stolones and can also reproduce vegetatively. Therefore, the number of seed-producing panicles increases annually in the perennial hybrid.

Natural hybrids of $C$. × gracilescens have been described from Sweden (Nygren 1962), Germany (Scholz 1964) and Great Britain (Crackles 1994, 1995). However, partly or totally different sets of characters differentiated the hybrid in each case. According to Hämet-Ahti et al. (1998) C. × gracilescens is a polymorphic taxon. Nygren (1962) used callus hair length, length of glumes, structure of the upper leaf surface, culm branching, presence of long hairs on the upper leaf surface and number of culm nodes. Nygren (1962) claimed that two stricta-like characters, the structure of the upper leaf surface and the number of culm nodes, as well as one canescens-like character, culm branching, are dominant characters. Leaf hairiness, a canescens-like character, is less dominant in $C$. $\times$ gracilescens according to Nygren (1962).

Scholz (1964) described $C$. × gracilescens as plants with characters intermediate between $C$. canescens and $C$. strict $a$ and believed that they are similar to $C$. villosa in spikelet morphology. Two diagnostic characters of $C$. × gracilescens were found by Scholz (1964) in the vegetative habit. The first is the leaf surface which is of the stricta-type and the second is culm branching which is of the canescens-type according to him. C. × gracilescens may be distinguished from $C$. villosa by the upper leaf surface: $C$. villosa does not have any ribs on the upper leaf surface. 
Interestingly, Crackles $(1994,1995)$ used totally different sets of characters to study morphological variation of hybrids between $C$. canescens and $C$. stricta. The following groups of characters were chosen by him to study the morphological variation of hybrids occurring along the Leven Canal, SE Yorks.: culm-related (width at 2nd node, culm rough near panicle, hairiness of bottom leaf sheath), panicle-related (length and width, length of basal branch of panicle) and spikelet-related (glume length and width, callus hairs length, awn length, awn insertion, ligule length). Two diagnostic characters (culm branching and structure of the upper leaf surface), selected by Nygren (1962) and Scholz (1964), were omitted in his studies. Crackles (1994) delimits morphological variation of $C$. stricta on the basis of culm height (up to $95 \mathrm{~cm}$ ), panicle length (up to $14 \mathrm{~cm}$ ) and length of the bottom branch of the panicle (up to 4 $\mathrm{cm}$ ). These traits were found to have a great discriminatory power between the two species studied by Crackles (1994, 1995). Such a discrepancy might be caused by slight differences in the environmental conditions experienced by the populations analyzed by him and those analyzed in the present study.

The pattern of morphological variation of $C$. stricta throughout its entire distribution area is unknown. According to Conert (1989), C. stricta is a rather invariable species in Europe. However, according to Tzvelev (1976), five subspecies of the widespread and circumboreal $C$. neglecta (Ehrh.) Gaertn. s. lato occur in the former USSR: subsp. neglecta, subsp. inexpansa (A. Gray) C.W. Greene, subsp. stricta (Timm) Tzvel., subsp. micrantha (Kearney) Tzvel., and subsp. groenlandica (Schrank) Matuszk. In North America, Mar et al. (2007) distinguished two subspecies: C. stricta subsp. stricta and C. stricta subsp. inexpansa. Matuszkiewicz (1948) listed two forms within C. neglecta: f. laxa Griseb. (panicle with long branches) and f. interrupta Prahl (panicle branches very short and panicle interrupted) without, however, giving actual numerical values. According to many authors (Matuszkiewicz 1948; Falkowski 1982; Szafer et al. 1988; Conert 1989; Hubbard 1968; Cracles 1994; Aiken et al. 1999; Marr et al. 2007) who describe the variation of $C$. stricta s. stricto, its height is nearly always delimited up to $100 \mathrm{~cm}$, length of panicle up to $15 \mathrm{~cm}$, seldom up to $20 \mathrm{~cm}$, and length of basal lateral branches of panicle up to $4 \mathrm{~cm}$. However, the height of $53 \%$ of individuals of C. stricta collected in Zbijów Mały is greater than $100 \mathrm{~cm}$. Some have also a very long panicle (up to $25 \mathrm{~cm}$ ) and long basal lateral branches of the panicle (up to $9.2 \mathrm{~cm}$ ). Variation in culm and panicle length and the length of the bottom panicle branch needs detailed evaluation between and within $C$. canescens and $C$. stricta. These characters do not seem to differ between the two parental species of $C$. × gracilescens. However, further studies with greater numbers of plants are required.

Plants from controlled reciprocal crosses between $C$. $c a$ nescens and $C$. stricta were produced by Nygren (1962). $\mathrm{F}_{1}$ plants as well as the second generation can be morphologically distinguished by two $C$. canescens-like characters (culm branching, presence of long white hairs on the upper leaf surface) and two $C$. stricta-like characters (structure of upper leaf surface, number of culm nodes). According to Nygren (1962), hairiness of the upper leaf surface varies considerably in several pure species and hybrids of Calamagrostis in different years. Natural hybrids from Sweden fit very well with $F_{1}$ plants on the basis of callus hairs and glume length, structure of the upper leaf surface and type of ligule, but differ in having an intermediate number of culm nodes (4) and in culm branching (36\% have a branched culm) (Nygren 1962). According to Nygren (1962), the node number normally varies between 1-3 in $C$. neglec$t a$, while $C$. canescens has between 4-6 nodes. Natural hybrids of $C . \times$ gracilescens detected in Poland resemble Swedish hybrids in callus hair length and the structure of the upper leaf surface.

The occurrence of Calamagrostis xgracilescens in Poland in the area of sympatry of their putative parental species, $C$. canescens and $C$. stricta, was confirmed based on morphology, gene flow indicated by AFLP markers, and information collected during field studies. The Polish hybrid accessions from Zbijów Mały exemplifies the difficulty of detecting hybridization based entirely on morphological characters. Morphological characters typically have an unknown but presumably complicated genetic basis and a nonheritable component that is difficult to estimate. These natural hybrids are not easy to found in natural conditions. However, amongst several hybrids within the genus Calamagrostis, C. ×gracilescens is the most common one, especially on the Scandinavian Peninsula.

\section{ACKNOWLEDGEMENTS}

This study was financially supported by the State Committee for Scientific Research of Poland, grant no. 2 P04G 04930. Beata Paszko would like to thank all people which were helpful during field studies. Fieldwork in Sweden and Finland has been made all the more memorable by the companionship of many of her friends: Lennart Stenberg (Stockholm, Sweden), Lennart Persson (Jönköping, Sweden), Bengt Nilsson (Sölvesborg, Sweden), and Jouko Sipari (Tampere, Finland).

\section{LITERATURE CITED}

AIKEN S.G., DALLWITZ M.J., CONSAUL L.L., MCJANNET C.L., GILLESPIE L.J., BOLES R.L., ARGUS G.W., GILLETT J.M., SCOTT P.J., ELVEN R., LEBLANC M.C., BRYSTING A.K., SOLSTAD H. 1999 onwards. Flora of the Canadian Arctic Archipelago: Descriptions, Illustrations, Identification, and Information Retrieval. Version: 29th April 2003. http://www.mun.ca/biology/delta/arcticf/

CHEFFINGS C.M. 2004. New Plant Status Lists for Great Britain. BSBI News 95: 36-43.

CHEFFINGS C.M., FARRELL L. (eds), Dines T.D., Jones, R.A., Leach S.J., mckean D.R., Pearman D.A., Preston C.D., Rumsey F.J., Taylor I. 2005. The Vascular Plant Red Data List for Great Britain. Species Status 7: 1-116. Joint Nature Conservation Committee, Peterborough.

CLAYTON W.D., RENVOIZE S.A. 1986. Genera Graminum: grasses of the world. Kew Bull., Addit. Ser. 13: 1-389.

CONERT H.J. 1989. Calamagrostis. In: Gustav Hegi Illustrierte Flora von Mittel-Europa. Conert H.H., Hamann U., SchultzeMotel W., Wagenitz G. (eds). Paul Parey, Berlin-Hamburg, Vol. 1(3), pp. 357-380. (in German)

CORPORAAL A. 1984. Calamagrostis $\times$ gracilescens (Blytt) Blytt nieuw voor Nederland. Gorteria 12: 109-111.

CRACKLES F.E. 1994. Calamagrostis stricta (Timm) Koeler, C. canescens (Wigg.) Roth and their hybrids in S.E. Yorks., c. 61, northern England. Watsonia 20: 51-60. 
CRACKLES F.E. 1995. A graphical analysis of the characters of Calamagrostis stricta (Timm) Koeler, C. canescens (Wigg.) Roth and their hybrid populations in S. E. Yorks., v.c. 61, northern England. Watsonia 20: 397-404.

EXCOFFIER LAVAL L.G., SCHNEIDER S. 2005. Arlequin ver. 3.0: An integrated software package for population genetics data analysis. Evolutionary Bioinformatics Online 1: 47-50.

FALKOWSKI M. (ed.) 1982. Trawy polskie. PWRiL, Warszawa. pp. 565. (in Polish)

FELSENSTEIN J. 1985. Confidence limits on phylogenies: an approach using the bootstrap. Evolution 39: 783-791.

HÄMET-AHTI L., SUOMINEN J., ULVINEN T., UOTILA P. (eds). 1998. Retkeilykasvio [Field Flora of Finland]. Ed. 4. Finnish Museum of Natural History, Botanical Museum, Helsinki. pp. 656. (in Finnish)

HOLMBERG O.R. (ed.). 1922. Hartmans handbok in Skandinaviens flora. Häfte 1. P. A. Norstedt \& Söners Förlag, Stockholm, pp. 160. (in Swedish)

HUBBARD C.E. 1968. Grasses. A guide to their structure, identification, uses, and distribution in the British Isles. 2nd ed. Penguin Books, Harmondsworth, Middlesex, UK. pp. 463.

KARLSSON T., CHRISTOFFERSON J. 2007. Ängsrör [Calamagrostis canescens $\times$ stricta]. In: Smålands flora. Edqvist M., Karlsson T. (eds). SBF-förlaget, Uppsala, Vol. 2, pp. 166. (in Swedish)

MARR K.L., HEBDA R.J., GREENE C.W. 2007. Calamagrostis Adans. In: Flora of North America North of Mexico, Magnoliophyta: Commelinidae (in part): Poaceae. Part 1. Barkworth M.E., Capels K.M., Long S., Anderton L.K., M.B. Piep (eds). Oxford University Press, New York, Vol. 24, pp. 706-732.

MATUSZKIEWICZ W. 1948. Materials to the monography of the genus Calamagrostis Adans. Annales Universitatis Mariae Curie-Skłodowska Sectio C 3(7): 223-258.

MATUSZKIEWICZ W. 2001. Przewodnik do oznaczania zbiorowisk roślinnych Polski. Vademecum Geobotanicum 3. Wydawnictwo Naukowe PWN, Warszawa, pp. 537.

MIREK Z., PIEKOŚ-MIRKOWA H., ZAJĄC A., ZAJĄC M. 2002. Flowering plants and pteridophytes of Poland - a checklist. In: Biodiversity of Poland. Mirek Z. (ed.), W. Szafer Institute of Botany, Polish Academy of Sciences, Kraków, Vol. 1, pp. $1-442$.

NEI M., LI W.H. 1979. Mathematical model for studying genetical variation in terms of restriction endonucleases. Proc. Natl. Acad. Sci., USA 76: 5269-5273.

NOBIS M. 2007. Rośliny naczyniowe zachodniej części Przedgórza Iłżeckiego. Vascular plants of the west part of Iłża Foreland (Małopolska Uplan). Prace Bot. 40: 1-458. (in Polish with English summary)

NOBIS M., PIWOWARCZYK R. 2004. New localities of rare and protected vascular plants on the Iłża Foreland (Małopolska
Upland). Part II. Fragm. Flor. Geobot. Polonica 11: 19-26. (in Polish with English summary)

NYGREN A. 1946. The genesis of some Scandinavian species of Calamagrostis. Hereditas 32: 131-262.

NYGREN A. 1962. Artificial and natural hybridization in European Calamagrostis. Symb. Bot. Upsal. 17(3): 1-105.

OCHYRA R., ŻARNOWIEC J., BEDNAREK-OCHYRA H. 2003. Census Catalogue of Polish Mosses. Polish Academy of Sciences, Institute of Botany, Kraków, pp. 372.

PALMGREN A. 1933-1934. Calamagrostis lanceolata Roth $\times$ C. neglecta (Ehrh.) ny för Åland. Memoranda Soc. Fauna Fl. Fennica 10: 51-52. (in Swedish)

PASZKO B., NOBIS M. 2007. Calamagrostis $\times$ gracilescens $(\mathrm{Po}-$ aceae) - nowy takson we florze Polski (Calamagrostis $\times$ gracilescens (Poaceae) - a new taxon in the flora of Poland). Botanika w Polsce - sukcesy, problemy, perspektywy. Streszczenia referatów i plakatów. pp. 97. 54 Zjazd Polskiego Towarzystwa Botanicznego, Szczecin, 3-8 września 2007.

PEER van de Y., WACHTER de R. 1994. TREECON for Windows: a software package for the construction and drawing of evolutionary trees for the Microsoft Windows environment. Comput. Applic. Biosci. 9: 569-570.

PRESTON C.D., PEARMAN D.A., DINES T.D. (eds). 2002. New Atlas of the British and Irish Flora. Oxford University Press, Oxford, pp. 910.

PRITCHARD J.K., WEN X., FALUSH D. 2009. Documentation for structure software: version 2.3. Department of Human Genetics: University of Chicago, Department of Statistics: University of Oxford.

RIESEBERG L.H. 1995. The role of hybridization in evolution: old wine in a new skins. Am. J. Bot. 82: 944-953.

SCHOLZ H. 1964. Zur Gramineenflora Mittleeuropas II. Ber. Deutsch. Bot. Ges. 77: 145-160.

STATSOFT INC. 2007. STATISTICA (data analysis software system), version 8.0. www.statsoft.com.

SZAFER W., KULCZYŃSKI S., PAWŁOWSKI B. 1988. Rośliny polskie. Opisy i klucze do oznaczania wszystkich gatunków roślin naczyniowych rosnących w Polsce bądź dziko, bądź też zdziczałych lub częściej hodowanych. PWN, Warszawa, pp. 1119.

TZVELEV N.N. 1976. Zlaki SSSR [English translation, A. A. Balkema/ Rotterdam Amerid Publishing Co. New Delhi. 1984]. Nauka Publishers, Leningrad Section, Leningrad, pp. 788.

VOS P., HOGERS R., BLEEKER M., REIJANS M., LEE van de T., HORNES M., FRITERS A., POT J., PALEMAN J., KUIPER M., ZABEAU M. 1995. AFLP: a new technique for DNA fingerprinting. Nucleic Acid Res. 23: 4407-4414.

ZAJĄC A. 1978. Założenia metodyczne Atlasu rozmieszczenia roślin naczyniowych w Polsce. Wiad. Bot. 22 (3): 145-155.

\section{APPENDIX 1}

List of Calamagrostis samples studied in AFLP analysis. Vouchers were deposited in KRAM.

Calamagrostis $\times$ gracilescens $($ Blytt) Blytt (19 specimens) Poland: gr-201, gr-202, gr-203 - Zbijów Mały, 51 ${ }^{\circ} 10^{\prime} 28.2^{\prime}$ ' N/021 $01 ' 55.1$ ' E, 2007-06-17, leg. B. Paszko; gr-204, gr-205 - Zbijów Mały, 51¹0’28.8', N/021 ${ }^{\circ} 01$ '58.8" E, 2007-06-17, leg. B. Paszko; gr-206, gr207, gr-208 - Zbijów Mały, 51 '10'28.9' N/021 01'53.1'” E, 2007-06-17, leg. B. Paszko; SWEDEN: gr-187, gr-188, gr-189 - Hunna, W shore of Lake Skatelövfjorden, 56 43'03.04" N/014³5'25.27' E, 2008-06-25, leg. B. Paszko \& B. Nilsson; gr-192 - Singö Island, ca. $3 \mathrm{~km} \mathrm{~N}$ of Singö, 60¹1'47.0” N/01844'11.9”' E, 2007-07-31, leg. B.
Paszko \& L. Stenberg; gr-194, gr-195, gr-196, gr-197 W of Vrankunge, Kiaholmen Island in Lake Skatelövfjorden, 56 42'59.03" N/014³6'55.13” E, 2008-06-25, leg. B. Paszko, B. Nilsson \& L. Persson; gr-198, gr-199, gr-200 W of Vrankunge, Kiaholmen Island in Lake Skatelövfjorden, 56 42'56.08" N/014³6’44.05” E, 2008-06-25, leg. B. Paszko, B. Nilsson \& L. Persson

Calamagrostis stricta (Timm) Koeler (16 specimens) Poland: st-213, st-214, st-215 - Zbijów Mały, 51 ${ }^{\circ} 10^{\prime} 29.3^{\prime}$ ' N/021 $01^{\prime} 52.7^{\prime}$ E, 2007-06-17, leg. B. Pa- 
szko; ICELAND: st-216, st-217 - Lonkot, close to the beach, 66 00'20.7" N [66 00.345 N]/019 $24^{\circ} 07.8^{\prime \prime} \mathrm{W}$ [019²4.130 W], 2007-07-23, leg. L. Persson; st-218 Skútustagòir, by the small Stakhólstjörn Lake located near the big Mývatn Lake, 66³4'05.0" N/01701'55.0” W, 2007-07-25, leg. L. Persson; Sweden: st-222, st-223, st224 - S of Lake Hammarsjön, 58 02'24.98' N/01350' 13.34" E, 2008-06-29, leg. B. Paszko \& L. Persson; st-225 - Blädinge village, shore of Lake Salen, 56 50'55.66" N/014³1'56.90" E, 2008-06-26, leg. B. Paszko \& L. Persson; st-226, st-227 - Bronholm, 57 $19^{\prime} 32.15^{\prime \prime} \mathrm{N} / 014^{\circ} 27^{\prime}$ 56.65" E, 2008-06-26, leg. B. Paszko \& L. Persson; st-228 - Skämershult, Lake Möllesjön, 56 23'20.63' N/014²7' 45.24" E, 2008-06-23, leg. B. Paszko \& B. Nilsson; st-231 - ca. $1.5 \mathrm{~km}$ W of Jarhois, 66 $56^{\circ} 43.47^{\prime \prime}$ N/023 $48^{\circ} 28.38^{\prime \prime}$ E, 2007-07-13, leg. B. Paszko, L. Stenberg \& J. Sipari; st232 - ca. $14 \mathrm{~km} \mathrm{SW}$ of Tärendö, ca. $8 \mathrm{~km} \mathrm{NW}$ of Aho, 6659'43.30" N/022³4'25.84” E, 2007-07-14, leg. B. Paszko, L. Stenberg \& J. Sipari; st-233 - ca $8 \mathrm{~km}$ E of Lillselet, 66³3'59.79” N/02252’45.58” E, 2007-07-16, leg. B. Paszko, L. Stenberg \& J. Sipari
Calamagrostis canescens (Wigg.) Roth (18 specimens) Czech Republik: ca-273 - W of Svetnov, 49³7'05.15' N/015 56'52.29" E, 2007-07-03, leg. B. Paszko; FinLAND: ca-272 - Lammiupää, 61 09'37.67” N/027³3'15.19” E, 2008-07-20, leg. B. Paszko \& J. Sipari; Poland: ca-209, ca-210 - Zbijów Mały, 51¹0'28.9', N/021 01'53.1" E, 2007-06-17, leg. B. Paszko; ca-211, ca-212 - Zbijów Mały, 51 '10'27.7''/021 01'54.8' E, 2007-06-17, leg. B. Paszko; SWEDEN: ca-190, ca-191 - Hunna, shore of Lake Skatelövfjorden, 5643'03.04" N/014³5'25.27' E, 2008-0625, leg. B. Paszko \& B. Nilsson; ca-193, ca-275, ca-276Singö Island, ca. $3 \mathrm{~km} \mathrm{~N}$ of Singö, 60'11'47.0" N/01844'11.9"' E, 2007-07-31, leg. B. Paszko \& L. Stenberg; ca-261, ca-262 - between Bergkvara and Gemla by, 56 52'51.66" N/01441'46.71" E, 2008-06-26, leg. B. Paszko \& L. Persson; ca-264 - W of Kullen, 56 20'15.02" N/013 ${ }^{\circ} 19^{\prime} 21.65^{\prime \prime}$ E, 2008-06-23, leg. B. Paszko \& B. Nilsson; ca-265 - N of Ynde, 56 $05^{\prime} 00.11^{\prime \prime} \mathrm{N} / 014^{\circ} 33^{\prime} 26.09^{\prime}$ E, 2008-06-24, leg. B. Paszko \& B. Nilsson; ca-266-W of Vrankunge, Kiaholmen Island in Lake Skatelövfjorden, 56 42'56.44" N/014³6'52.56" E, 2008-06-25, leg. B. Paszko, B. Nilsson \& L. Persson; ca-268 - Västra Fagerhult, 5746'07.84" N/01441'33.18" E, 2008-06-28, leg. B. Paszko \& L. Persson; ca-269 - Stockholm, S side of Lake Brunnsvikens, 59¹9'46.81" N/01807'22.34” E, 2008-0701, leg. B. Paszko \& P. S. Lindberg 